\title{
ANALISIS KELAYAKAN PADA INVESTASI HOTEL XY DI KALIMANTAN BARAT
}

\author{
Widiya Putri, Naomi Nessyana Debataraja, Evy Sulistianingsih
}

\begin{abstract}
INTISARI
Analisis kelayakan investasi merupakan suatu alat bantu bagi perusahaan dalam pengambilan keputusan investasi, apakah investasi tersebut layak untuk diteruskan atau tidak. Analisis kelayakan investasi dapat dilakukan menggunakan beberapa metode diantaranya adalah net present value (NPV), internal rate of return (IRR), dan payback period (PP). Investasi akan menghasilkan keuntungan jika nilai NPV yang dihasilkan lebih dari nol atau dengan kata lain, nilai discount rate yang diperoleh lebih besar dari bunga relevan, dan modal investasi dapat dikembalikan lebih cepat dari jangka waktu peminjaman jika nilai $P P$ lebih kecil dari jangka waktu investasi. Penelitian ini menggunakan data hotel XY yaitu data luas tanah, luas bangunan, jumlah lantai gedung, jumlah kamar, tipe kamar, koefisien tiap lantai bangunan, harga satuan tanah, harga sewa kamar, dan sumber dana proyek. Tujuan penelitian ini adalah untuk menganalisis kelayakan pada investasi hotel XY. Berdasarkan analisis diperoleh nilai NPV sebesar Rp23.025.467.095, nilai IRR sebesar 17,645\% lebih besar dari tingkat suku bunga 12\% (17,645\% > 12\%), dan PP diperoleh hasil yaitu 5 tahun 8 bulan. Dengan perolehan tersebut dapat disimpulkan bahwa investasi proyek pembangunan hotel XY layak untuk dilanjutkan.
\end{abstract}

Kata Kunci: Net Present Value, Internal Rate of Return, Payback Period

\section{PENDAHULUAN}

Investasi adalah kegiatan menarik dana kemudian menggunakannya untuk membeli barang modal pada saat sekarang dan mengusahakan terwujudnya laba di masa yang akan datang [1]. Investasi berhadapan dengan masa mendatang yang penuh ketidakpastian. Sebelum melaksanakan investasi perlu dilakukan analisis kelayakan investasi guna menentukan investasi tersebut dapat dilaksanakan dengan memperoleh keuntungan atau sebaliknya. Analisis kelayakan investasi adalah penelitian terhadap suatu investasi (khususnya investasi proyek) layak atau tidak dilaksanakan. Kriteria yang digunakan untuk mengukur kelayakan suatu investasi adalah net present value (NPV), internal rate of return (IRR), dan payback period (PP).

Net present value (NPV) adalah selisih antara PV cash flow terhadap PV investasi selama masa investasi, atau dengan kata lain merupakan nilai cash flow yang diperkirakan pada masa yang akan datang yang didiskon pada saat ini[2]. Cash flow (aliran kas) merupakan peninjauan pada aspek finansial yang memberikan informasi tentang penerimaan dan pengeluaran kas suatu perusahaan dilakukan pada suatu periode tertentu dengan mengklasifikasikan transaksi pada kegiatan operasi, pembiayaan, dan investasi [3].

Internal rate of return (IRR) merupakan besarnya suku bunga yang menjadikan biaya pengeluaran dan pendapatan sama besarnya dan NPV sama dengan nol [4]. Dengan demikian, dapat dikatakan bahwa suatu investasi menguntungkan nilai discount rate yang dihasilkan lebih besar dari tingkat suku bunga. Payback Period (PP) dapat digunakan untuk mengetahui seberapa lama waktu yang dibutuhkan untuk biaya investasi dapat dikembalikan. Jika waktu yang dihasilkan dengan menggunakan payback period lebih kecil dari masa investasi maka dapat dikatakan bahwa investasi tersebut layak untuk dilakukan pembangunan.

Data yang digunakan pada penelitian ini adalah data hotel XY sebagai hotel kelas bintang tiga yang akan dibangun pada kawasan Provinsi Kalimantan Barat. Gedung hotel ini berupa bangunan 
empat lantai dengan masing-masing luas bangunan $1.436 \mathrm{~m}^{2}, 1.215 \mathrm{~m}^{2}, 1.215 \mathrm{~m}^{2}$, dan $742 \mathrm{~m}^{2}$, dengan luas lahan bangunan $5.500 \mathrm{~m}^{2}$ dan dapat menampung kapasitas 60 kamar. Langkah pertama yang dilakukan yaitu menentukan biaya investasi hotel yang terdiri dari biaya langsung dan biaya tidak langsung. Biaya langsung terdiri dari harga satuan tanah, harga satuan gedung, dan biaya bangunan. Biaya tidak langsung terdiri dari biaya tambahan, biaya dekorasi, biaya perlengkapan, biaya lapangan dan landscaping, serta biaya cadangan. Setelah mendapatkan hasil dari biaya investasi, langkah selanjutnya adalah penentuan nilai cash flow (aliran kas) yang diperoleh dari perhitungan nilai pendapatan dan nilai pengeluaran. Nilai pendapatan yang berasal dari pendapatan kotor dan pendapatan bersih hotel. Kemudian, nilai pengeluaran dihitung dari biaya operasional, biaya asuransi, dan biaya pajak perseroan. Selanjutnya, dilakukan perhitungan analisis kelayakan investasi dengan metode net present value (NPV), internal rate of return (IRR), dan payback period (PP). Langkah terakhir yang dilakukan adalah pengambilan keputusan yang bertujuan untuk menentukan apakah investasi layak untuk dilakukan pembangunan atau tidak.

\section{TEORI BUNGA DAN DISCOUNT RATE}

Bunga ( $i$ ) adalah kompensasi yang dibayar oleh peminjam kepada pemberi pinjaman karena penggunaan modal usaha tersebut. Bentuk kompensasi tidak harus sama dengan hasil keuntungan, tetapi pada hampir semua kasus hasil keuntungan dan kompensasi dinyatakan dalam bentuk satuan uang. Bunga dibayar di akhir periode dan diperhitungkan dari jumlah investasi awal periode, perhitungan bunga terdiri dari dua yaitu bunga sederhana dan bunga majemuk. Bunga sederhana hanya diperhitungkan satu kali untuk satu periode terhadap jumlah pokok yang besarnya tetap. Bunga majemuk yang sering disebut bunga berbunga, menunjukkan bunga ditambah pokok pinjaman yang dikenakan bunga pada periode berikutnya sehingga dari periode ke periode jumlah pokok menjadi semakin besar yang merupakan akumulasi dari penambahan bunga tersebut[5].

Faktor diskonto $(d)$ adalah rasio jumlah bunga terhadap jumlah investasi pada akhir periode. Faktor diskonto $(d)$ dibayar di awal periode tetapi diperhitungkan dari jumlah investasi pada akhir periode. Asumsikan bahwa seseorang meminjam sebesar 1 pada tingkat diskonto efektif $d$, kemudian berlaku pokok awal adalah $(1-d)$ dan jumlah bunga (diskonto) adalah $d$. Berdasarkan definisi dasar suku bunga (i) sebagai suatu rasio dari sejumlah bunga pokok awal, maka diperoleh persamaan berikut.

$$
i=\frac{d}{1-d}
$$

Persamaan (1) dapat dijabarkan dengan menggunakan aljabar sederhana sehingga diperoleh persamaan sebagai berikut.

$$
d=\frac{i}{1+i}
$$

\section{PRESENT VALUE}

Present value adalah nilai sekarang dari sejumlah uang yang akan dibayar pada masa yang akan datang. Pada prinsipnya proses menghitung present value adalah proses diskonto yang dirumuskan sebagai berikut [6]:

$$
P V=F V\left[\frac{1}{(1+i)}\right]^{n}
$$

dengan $P V$ adalah present value (nilai sekarang) pada periode waktu ke- $n, F V$ adalah nilai masa depan (future vaue), $i$ adalah suku bunga, $n$ adalah lama periode. 


\section{BIAYA INVESTASI}

Biaya investasi dibagi lagi menjadi 2 tahapan, yaitu biaya langsung dan biaya tidak langsung. Biaya langsung adalah biaya tahap awal pembangunan sampai pada mulai beroperasinya hotel. Biaya tidak langsung adalah tahapan lainnya dari pengembangan yang dilakukan setelah mulai beroperasi. Biaya tidak langsung terdiri dari $20 \%$ biaya tambahan, $22 \%$ biaya perabotan dan dekorasi, $6 \%$ biaya perlengkapan, $1 \%$ biaya pekerja lapangan dan landscaping, dan $10 \%$ biaya cadangan[7].

\section{CASH FLOW}

Cash flow (aliran kas) merupakan peninjauan pada aspek finansial yang memberikan informasi tentang pendapatan dan pengeluaran kas suatu perusahaan dilakukan pada suatu periode tertentu[3]. Pendapatan adalah seluruh penerimaan baik berupa uang maupun berupa barang yang berasal dari pihak lain yang dinilai atas dasar sejumlah uang dari harta yang berlaku saat ini. Nilai dari pendapatan terdiri dari pendapatan kotor dan pendapatan bersih.

Nilai pendapatan kotor diantaranya diperoleh dari penjualan makanan dan minuman, dan penjualan sewa kamar hotel. Pendapatan dari penjualan sewa kamar bervariasi tergantung dari kelas atau bintang hotel serta fasilitas yang ditawarkan. Hasil penjualan diperoleh dari rumus berikut:

$$
R=h \times e \times 365 \times C \times r
$$

dengan $R$ adalah pendapatan sewa kamar, $h$ adalah tingkat hunian, $e$ adalah koefisien pendapatan hotel (biasanya digunakan 2,5), $C$ adalah jumlah kamar, 365 adalah jumlah hari dalam setahun, dan $r$ adalah harga sewa kamar. Pendapatan sewa kamar hotel diasumsikan mengalami kenaikan harga sebesar 5\% per tahun. Pendapatan diluar sewa kamar besarnya adalah $150 \%$ dari sewa kamar untuk hotel[8]. Nilai pendapatan suatu bangunan tidak selalu menggunakan nilai koefisien. Nilai koefisien dengan ketetapan 2,5 merupakan nilai yang hanya digunakan untuk pembangunan gedung hotel[7].

Nilai pendapatan bersih diperoleh dari pendapatan kotor dikurangi dengan biaya operasional departemen. Biaya operasional departemen terdiri dari biaya penjualan sewa kamar sebesar $17 \%$ dari hasil nilai pendapatan sewa kamar, biaya penjualan makanan dan minuman sebesar $40 \%$ dari hasil nilai pendapatan makanan dan minuman, dan biaya penjualan lainnya sebesar $20 \%$ dari hasil nilai pendapatan lainnya[9].

Pengeluaran merupakan pembayaran yang dilakukan saat ini untuk kewajiban pada masa yang akan datang dalam rangka memperoleh beberapa keuntungan, nilai pengeluaran hotel terdiri dari biaya operasional, biaya asuransi dan pajak perseroan[8]. Besarnya pajak perseroan tergantung berapa banyak investor akan memperoleh pendapatan kotor. Pada penelitian ini diperoleh nilai pendapatan kotor lebih dari 50 miliar dengan nilai pajak dihitung sebesar $25 \%$ dari penghasilan kena pajak. Perhitungan penghasilan kena pajak diperoleh dari pendapatan kotor dikurangi biaya operasional, biaya asuransi, pengeluaran untuk pembayaran bunga pinjaman, dan depresiasi[7].

\section{METODE INTERPOLASI LINIER}

Interpolasi linier adalah suatu bentuk interpolasi untuk menentukan titik-titik yang berada diantara titik-titik yang diketahui menggunakan fungsi pendekatan yang berupa fungsi linier. Oleh karena itu diperoleh sejumlah titik diantara dua titik $\left(x_{1}, y_{1}\right)$ dan $\left(x_{2}, y_{2}\right)$. Metode ini digunakan untuk mengetahui nilai dari suatu titik yang berbeda didalam sebuah interval atau diantara dua buah titik yang segaris[10]. Rumus untuk metode interpolasi linier yaitu sebagai berikut:

$$
y=y_{1}+\left[\frac{\left(x_{1}\right) \cdot\left(y_{2}-y_{1}\right)}{\left(x_{2}-x_{1}\right)}\right]
$$




\section{NET PRESENT VALUE (NPV)}

Nilai yang dikeluarkan untuk mendapatkan nilai lain yang akan diterima di masa depan disebut dengan nilai saat ini (present value) dari jumlah tersebut. Nilai bersih saat ini (net present value) dari suatu investasi modal adalah selisih antara PV cash flow terhadap PV investasi selama masa investasi, atau dengan kata lain merupakan nilai cash flow yang diperkirakan pada masa yang akan datang yang didiskon pada saat ini[2]. Metode ini menggunakan bunga diskonto yang mempengaruhi nilai cash flow (aliran kas) [5]. Nilai NPV dapat dihitung dengan rumus sebagai berikut:

$$
N P V=-C F_{0}+\sum_{j=1}^{n} \frac{C F_{j}}{(1+i)^{j}}
$$

dengan $N P V$ adalah nilai net present value, $C F_{0}$ adalah nilai cash flow pada periode waktu ke-0 atau bisa disebut sebagai nilai investasi awal, $C F_{n}$ adalah nilai cash flow pada periode waktu ke- $n$.

\section{INTERNAL RATE OF RETURN (IRR)}

Internal rate of return merupakan tingkat suku bunga yang menjadikan biaya pengeluaran dan pendapatan sama besarnya, hal tersebut menunjukkan bahwa suatu investasi menguntungkan jika nilai discount rate yang dihasilkan lebih besar dari tingkat suku bunga. IRR adalah discount rate yang menjadikan NPV sama dengan nol. Oleh karena itu, nilai IRR saat NPV sama dengan nol dapat diperoleh dengan melakukan percobaan perhitungan nilai NPV dengan tingkat suku bunga yang berbeda. Dengan demikian, dapat digunakan cara interpolasi untuk menghitung jumlah IRR sebagai berikut[4].

$$
I R R=i_{N P V_{(+)}}+\frac{N P V_{(+)}}{\left(N P V_{(+)}-N P V_{(-)}\right)} \times\left(i_{N P V_{(-)}}-i_{N P V_{(+)}}\right)
$$

dengan IRR adalah nilai internal rate of return, $i_{N P V_{(+)}}$adalah nilai suku bunga saat NPV positif, $i_{N P V_{(-)}}$ adalah nilai suku bunga saat NPV negatif, $N P V_{(+)}$adalah nilai NPV saat positif, $N P V_{(-)}$adalah nilai NPV saat negatif.

\section{PAYBACK PERIOD (PP)}

Menurut Umar (1999), payback period adalah suatu periode yang diperlukan untuk menutup kembali biaya investasi dengan mengguanakan cash flow. Dengan kata lain, payback period merupakan rasio antara biaya investasi dengan cash flow yang hasilnya merupakan suatu waktu. Rumus yang digunakan untuk menghitung payback period adalah sebagai berikut:

$$
P P=N+\frac{k_{n}-C F_{0}}{k_{n+1}}
$$

dengan $P P$ adalah nilai payback period, $N$ adalah nilai tahun terakhir dimana cash flow belum bisa menutupi biaya investasi, $k_{n}$ adalah jumlah kumulatif cash flow sampai tahun ke $n, k_{n+1}$ adalah jumlah kumulatif cash flow sampai tahun ke $n+1$.

\section{PENGAMBILAN KEPUTUSAN}

Suatu investasi diharapkan dapat memberikan nilai tambah yang positif. Dalam arti bahwa present value and cash flow yang akan dihasilkan di masa datang lebih besar daripada biaya-biayanya. Kriteria yang digunakan untuk mengukur kelayakan investasi suatu investasi adalah net present value (NPV), internal rate of return (IRR), dan payback period (PP). Pengambilan keputusan disesuaikan dengan $\underline{\text { kriteria dari setiap metode yang akan menentukan apakah investasi tersebut layak untuk dilanjutkan }}$ 
atau tidak. NPV dapat dikatakan layak jika hasil yang diperoleh bernilai positif. IRR dapat dikatakan layak jika hasil yang diperoleh lebih besar dari nilai discount rate. PP dapat dikatakan layak jika hasil yang diperoleh lebih kecil dari masa investasi. Pengambilan keputusan dapat dianggap sebagai suatu hasil dari proses perhitungan atau analisis yang selalu menghasilkan satu pilihan akhir[11].

\section{PEMBAHASAN}

Data penelitian yang digunakan pada penelitian ini merupakan data primer yaitu data hotel XY berupa data luas tanah, luas bangunan, jumlah lantai bangunan, luas perlantai bangunan, jumlah kamar, koefisien tiap lantai bangunan, harga satuan tanah, harga sewa kamar, dan sumber dana proyek. Adapun sumber dana yang digunakan investor untuk investasi pembangunan hotel XY adalah dari modal sendiri yaitu sebesar $25 \%$ dari biaya investasi dan modal pinjaman dari Bank Syariah Mandiri yaitu sebesar 75\% dari biaya investasi, dengan jangka waktu peminjaman pada pihak bank selama 15 tahun dan bunga pinjaman sebesar $12 \%$. Hotel XY merupakan hotel kelas bintang tiga yang akan dibangun di kawasan Provinsi Kalimantan Barat. Kriteria klasifikasi hotel bintang tiga adalah jumlah kamar standar paling sedikit 50 kamar, kamar deluxe paling sedikit 3 kamar, kamar mandi di dalam, luas kamar standar $30 \mathrm{~m}^{2}$, dan luas kamar suite $48 \mathrm{~m}^{2}$. Harga masing-masing tipe kamar hotel yaitu Rp436.800 untuk tipe kamar standar, Rp742.560 untuk tipe kamar deluxe, dan Rp975.520 untuk tipe kamar suite.

Harga satuan gedung berdasarkan harga yang berlaku di kawasan Provinsi Kalimantan Barat untuk gedung bertingkat adalah sebesar Rp5.000.000/ $\mathrm{m}^{2}$ dan harga tanah dikisaran Rp5.000.000/ $\mathrm{m}^{2}$. Gedung hotel ini berupa bangunan empat lantai dengan luas lahan bangunan hotel yaitu sebesar $5.500 \mathrm{~m}^{2}$. Luas bangunan perlantai untuk hotel XY yaitu lantai 1 sebesar $1.436 \mathrm{~m}^{2}$, lantai 2 sebesar $1.215 \mathrm{~m}^{2}$, lantai 3 sebesar $1.215 \mathrm{~m}^{2}$, lantai 4 sebesar $742 \mathrm{~m}^{2}$.

\section{PENENTUAN BIAYA INVESTASI}

Biaya investasi yang dibutuhkan untuk pembangunan hotel XY terdiri dari biaya langsung dan biaya tidak langsung. Biaya langsung pembangunan hotel XY yaitu berupa biaya pembelian tanah sebesar Rp27.500.000.000 dan biaya bangunan sebesar Rp20.605.270.000. Biaya tidak langsung terdiri dari biaya tambahan 20\% dari biaya bangunan sebesar Rp4.121.150.000, biaya perabotan dan dekorasi 22\% dari biaya bangunan sebesar Rp4.533.265.000, biaya perlengkapan 6\% dari biaya bangunan sebesar Rp1.236.345.000, biaya pekerja lapangan dan landscaping 1\% dari biaya bangunan sebesar Rp103.028.750. Kemudian terdapat biaya cadangan 10\% dari total biaya langsung dan tidak langsung sebesar Rp5.809.953.875. Tabel 2 berikut adalah rincian biaya investasi.

Tabel 2. Biaya Investasi

\begin{tabular}{|c|c|c|c|c|}
\hline Komponen & $\begin{array}{c}\text { Luas Satuan } \\
\left(\mathbf{m}^{2}\right)\end{array}$ & $\begin{array}{c}\text { Koefisien } \\
\text { Bangunan }\end{array}$ & $\begin{array}{c}\text { Harga Satuan } \\
\text { (Rp) }\end{array}$ & Biaya (Rp) \\
\hline Tanah & 5.500 & & 5.000 .000 & 27.500 .000 .000 \\
\hline Lantai 1 & 1.436 & 1,000 & 5.000 .000 & 7.180 .000 .000 \\
\hline Lantai 2 & 1.215 & 1,090 & 5.000 .000 & 6.621 .750 .000 \\
\hline Lantai 3 & 1.215 & 1,120 & 5.000 .000 & 6.804 .000 .000 \\
\hline \multicolumn{4}{|c|}{ Biaya Tidak Langsung } & 9.993 .788 .750 \\
\hline \multicolumn{4}{|c|}{ Biaya Cadangan } & 5.809 .953 .875 \\
\hline \multicolumn{4}{|c|}{ Total Biaya Investasi } & 63.909 .492 .625 \\
\hline
\end{tabular}




\section{PENENTUAN NILAI NET PRESENT VALUE (NPV)}

Pembangunan hotel XY membutuhkan biaya modal yang besar yaitu biaya investasi sebesar Rp63.909.492.625. Oleh karena itu, perusahaan melakukan peminjaman modal kepada pihak bank 75\% dari biaya investasi sebesar Rp47.932.119.469 dengan suku bunga 12\% dan jangka waktu 15 tahun. Hasil perolehan nilai NPV dapat dilihat pada Tabel 3.

Tabel 3. Perhitungan Nilai NPV

\begin{tabular}{ccrr}
\hline Tahun & Cash Flow $(\mathbf{R p})$ & Discount Factor & \multicolumn{1}{c}{ PV $(\mathbf{R p )}$} \\
\hline $\mathbf{0}$ & -63.909 .492 .625 & 1 & -63.909 .492 .625 \\
$\mathbf{1}$ & 33.609 .668 .602 & 0,8929 & 9.142 .767 .131 \\
$\mathbf{2}$ & 35.626 .248 .718 & 0,7972 & 8.501 .568 .001 \\
$\mathbf{3}$ & 37.763 .823 .641 & 0,7118 & 7.907 .194 .460 \\
$\mathbf{4}$ & 40.029 .653 .059 & 0,6355 & 7.355 .996 .627 \\
$\mathbf{5}$ & 42.431 .432 .243 & 0,5674 & 6.844 .630 .230 \\
$\mathbf{6}$ & 44.977 .318 .177 & 0,5066 & 6.370 .029 .208 \\
$\mathbf{7}$ & 47.675 .957 .268 & 0,4523 & 5.929 .380 .906 \\
$\mathbf{8}$ & 50.536 .514 .704 & 0,4039 & 5.520 .103 .620 \\
$\mathbf{9}$ & 53.568 .705 .586 & 0,3606 & 5.139 .826 .250 \\
$\mathbf{1 0}$ & 56.782 .827 .921 & 0,3220 & 4.786 .369 .864 \\
$\mathbf{1 1}$ & 60.189 .797 .597 & 0,2875 & 4.457 .730 .975 \\
$\mathbf{1 2}$ & 63.801 .185 .453 & 0,2567 & 4.152 .066 .366 \\
$\mathbf{1 3}$ & 67.629 .256 .580 & 0,2292 & 3.867 .679 .321 \\
$\mathbf{1 4}$ & 71.687 .011 .974 & 0,2046 & 3.603 .007 .116 \\
$\mathbf{1 5}$ & 75.988 .232 .693 & 0,1827 & 3.356 .609 .646 \\
\hline \multicolumn{5}{c}{ Jumlah } & & $\mathbf{8 6 . 9 3 4 . 9 5 9 . 7 2 0}$ \\
\hline \multicolumn{5}{c}{ NPV } & $\mathbf{2 3 . 0 2 5 . 4 6 7 . 0 9 5}$ \\
\hline
\end{tabular}

Berdasarkan Tabel 3 dapat dilihat bahwa perhitungan nilai NPV diperoleh dengan mengurangi jumlah PV cash flow terhadap biaya investasi menghasilkan nilai NPV sebesar Rp23.025.467.095. Dengan demikian, dapat dikatakan bahwa investasi hotel XY diperkirakan memperoleh keuntungan sebesar Rp23.025.467.095.

\section{PENENTUAN NILAI INTERNAL RATE OF RETURN (IRR)}

Nilai IRR dapat diperoleh saat NPV sama dengan nol, hal tersebut didapat dengan mencari nilai NPV menggunakan discount rate bervariasi. Dilakukan percobaan mencari nilai NPV menggunakan discount rate bervariasi dengan rentang $16 \%$ - 19\%, kemudian diperoleh hasil bahwa nilai NPV sama dengan nol berada diantara $17 \%$ dan $18 \%$ dengan grafik berikut.

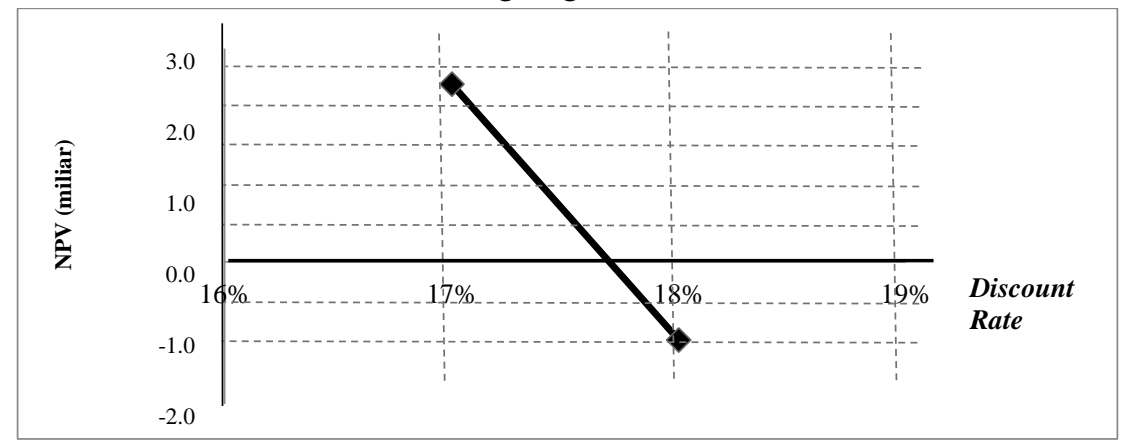

Gambar 1. Grafik NPV 
Berdasarkan Gambar 1 dapat dilihat persamaan garis lurus yang melalui dua titik dapat dikatakan bahwa nilai NPV sama dengan nol berada diantara $17 \%$ dan $18 \%$. Pada suku bunga $17 \%$ diperoleh nilai NPV sebesar Rp2.077.134.915 dan pada suku bunga 18\% diperoleh nilai NPV sebesar -Rp1.143.441.221. Selanjutnya, dilakukan perhitungan untuk memperoleh nilai IRR dengan cara interpolasi sebagai berikut.

$$
\begin{aligned}
& I R R=i N P V_{17 \%}+\frac{N P V_{17 \%}}{\left(N P V_{17 \%}-N P V_{18 \%}\right)} \times\left(i N P V_{18 \%}-i N P V_{17 \%}\right) \\
& I R R=17 \%+\frac{R p 2.077 .134 .915}{(R p 2.077 .134 .915-(-R p 1.143 .441 .221))} \times(18 \%-17 \%) \\
& I R R=17 \%+(0,645 \times 1 \%) \\
& I R R=17,645 \%
\end{aligned}
$$

Nilai IRR yang diperoleh dari proyek investasi selama 15 tahun dengan suku bunga $12 \%$ dan modal pinjaman sebesar Rp47.932.119.469 yaitu sebesar 17,645\% (17,645\% > 12\%). Artinya modal pinjaman yang diperoleh investor akan mengalami perkembangan sebesar 17,645\% selama jangka waktu 15 tahun dan akan memperoleh keuntungan.

\section{PENENTUN NILAI PAYBACK PERIOD (PP)}

Perhitungan nilai payback period digunakan untuk mengetahui berapa lama investasi akan kembali. Nilai payback period yang diperoleh dari tahun terakhir dimana cash flow belum bisa menutupi investasi, kumulatif cash flow, dan nilai investasi yang disajikan pada Tabel 4 berikut.

Tabel 4. Perhitungan Nilai Payback Period

\begin{tabular}{rrrrr}
\hline Tahun & Pendapatan Bersih(Rp) & Pengeluaran(Rp) & Cash Flow $(\mathbf{R p})$ & Kumulatif Cash Flow $($ Rp) \\
\hline $\mathbf{0}$ & & & 63.909 .492 .625 & -63.909 .492 .625 \\
$\mathbf{1}$ & 25.375 .299 .794 & 15.135 .400 .608 & 10.239 .899 .186 & -53.669 .593 .439 \\
$\mathbf{2}$ & 26.644 .064 .784 & 15.979 .697 .884 & 10.664 .366 .900 & -43.005 .226 .539 \\
$\mathbf{3}$ & 27.976 .268 .023 & 16.867 .229 .125 & 11.109 .038 .899 & -31.896 .187 .640 \\
$\mathbf{4}$ & 29.375 .081 .424 & 17.800 .278 .320 & 11.574 .803 .104 & -20.321 .384 .536 \\
$\mathbf{5}$ & 30.843 .835 .495 & 18.781 .258 .335 & 12.062 .577 .160 & -8.258 .807 .376 \\
$\mathbf{6}$ & 32.386 .027 .270 & 19.812 .719 .115 & 12.573 .308 .156 & 4.314 .500 .780 \\
$\mathbf{7}$ & 34.005 .328 .634 & 20.897 .356 .508 & 13.107 .972 .126 & 17.422 .472 .906 \\
$\mathbf{8}$ & 35.705 .595 .065 & 22.038 .021 .774 & 13.667 .573 .292 & 31.090 .046 .198 \\
$\mathbf{9}$ & 37.490 .874 .819 & 23.237 .731 .828 & 14.253 .142 .991 & 45.343 .189 .189 \\
$\mathbf{1 0}$ & 39.365 .418 .560 & 24.499 .680 .292 & 14.865 .738 .268 & 60.208 .927 .457 \\
$\mathbf{1 1}$ & 41.333 .689 .488 & 25.827 .249 .435 & 15.506 .440 .053 & 75.715 .367 .510 \\
$\mathbf{1 2}$ & 43.400 .373 .962 & 27.224 .023 .081 & 16.176 .350 .881 & 91.891 .718 .390 \\
$\mathbf{1 3}$ & 45.570 .392 .660 & 28.693 .800 .583 & 16.876 .592 .077 & 108.768 .310 .468 \\
$\mathbf{1 4}$ & 47.848 .912 .293 & 30.240 .611 .952 & 17.608 .300 .341 & 126.376 .610 .809 \\
$\mathbf{1 5}$ & 50.241 .357 .908 & 31.868 .734 .282 & 18.372 .623 .626 & 144.749 .234 .434 \\
\hline
\end{tabular}

Berdasarkan Tabel 4 dapat dilihat bahwa nilai payback period berada diantara tahun ke-5 sampai tahun ke-6. Hasil yang diperoleh yaitu nilai kumulatif cash flow pada tahun ke-5 sebesar -Rp8.258.807.376 dan nilai kumulatif cash flow pada tahun ke-6 sebesar Rp4.314.500.780. Dengan demikian dapat dilakukan perhitungan menggunakan cara interpolasi sebagai berikut.

$$
\begin{aligned}
& P P=N_{(-)}+\frac{k u m C F_{(-)}}{k u m C F_{(-)}-k u m C F_{(+)}} \times\left(N_{(+)}-N_{(-)}\right) \\
& P P=5+\frac{-R p 8.258 .807 .376}{(-R p 8.258 .807 .376-R p 4.314 .500 .780)} \times(6-5) \\
& P P=5+(0,66 \times 1)=5,66
\end{aligned}
$$


Dari perhitungan tersebut diperoleh nilai payback period yaitu 5,66 atau periode pengembalian berada diatara tahun ke-5 dan tahun ke-6. Hasil tersebut menunjukkan bahwa investasi hotel XY diperkirakan akan kembali selama 5 tahun 8 bulan dan hasil perhitungan ini menunjukkan nilai payback period lebih kecil dari pada masa investasi yaitu 15 tahun.

\section{PENUTUP}

Berdasarkan hasil penelitian yang telah dibahas dapat diambil kesimpulan bahwa usulan proyek investasi pembangunan hotel XY di Kalimantan Barat dapat dikatakan layak untuk dilanjutkan dan layak dari segi finansial, dikarenakan hasil analisis yang diperoleh yaitu nilai NPV dari hotel sebesar Rp23.025.467.095 menunjukkan bahwa nilai NPV lebih besar dari nol. Kemudian, IRR dari hotel sebesar $17,645 \%$ menunjukkan bahwa nilai IRR lebih besar dari nilai suku bunga $12 \%$ dan nilai PP yang diperoleh dari hotel sebesar 5 tahun 8 bulan. Hasil tersebut menunjukkan bahwa PP lebih kecil dari masa investasi hotel (5,8 tahun $<15$ tahun). Investasi diperkirakan akan mengalami keuntungan seperti yang diharapkan.

\section{DAFTAR PUSTAKA}

[1] Basalamah S. Studi Kelayakan Investasi: Proyek dan Bisnis. Jakarta, Bumi Aksara, 2010.

[2] Kasmir. Bank dan Lembaga Keuangan Lainnya. Jakarta, PT. Raja Grafindo, 2004

[3] Harahap. Akuntansi Aktiva Tetap (Ed 3). Jakarta, PT. Raja Grafindo, 2004.

[4] Kodoatie, Robert J. Analisa Ekonomi Teknik. Yogyakarta, Andi Offset, 1994.

[5] Kellison SG. The Teory of Interest (2th Ed). San Francisco, The McGraw-Hill Companies Inc, 2000.

[6] Fahmi I. Matematika Keuangan. Bandung, ALFABETA, 2015.

[7] Poerbo H. Dasar-Dasar Studi Kelayakan Proyek Perkantoran, Perhotelan Rumah Sakit, Apartemen. Jakarta, Djambatan, 1993.

[8] Suroto. Strategi Pembangunan dan Perencanaan Perancangan Kesempatan Kerja. Yogyakarta, UGM, 2000.

[9] Ramadhani F, Irwandi D, Darfia NE, Basri DR. Analisis Kelayakan Pada Investasi Hotel Novotel di Kota Pekanbaru. Jurnal Rab Construction Research. 2016; 1(2):106-119.

[10] Munir R. Metode Numerik (Ed 1). Bandung, Informatika, 2006.

[11] Umar. Metode Pay Back Period. Yogyakarta, Andi Offset, 1999.

[12] Djarwanto JS, Pangestu S. Statistik Induktif. Yogyakarta, BPFE, 1993.

[13] Hidayat A. Analisis Economic Enginnering Pada Investasi Hotel Grand Central Kota Pekanbaru. Jurnal Rab Construction Research. 2016; 1(2):106-119.

[14] Nufaili R, Utomo C. Analisis Investasi Hotel Pesonna Makassar. Jurnal Teknik POMITS. 2014; 3(2):143-146.

[15] Website resmi Badan Pusat Statistik (https://www.kalbar.bps.go.id)

WIDIYA PUTRI

NAOMI NESSYANA DEBATARAJA

EVY SULISTIANINGSIH
: Fakultas MIPA Universitas Tanjungpura, Pontianak, widyaputri@student.untan.ac.id

: Fakultas MIPA Universitas Tanjungpura, Pontianak, naominessyana@math.untan.ac.id

: Fakultas MIPA Universitas Tanjungpura, Pontianak, evysulistianingsih@math.untan.ac.id 